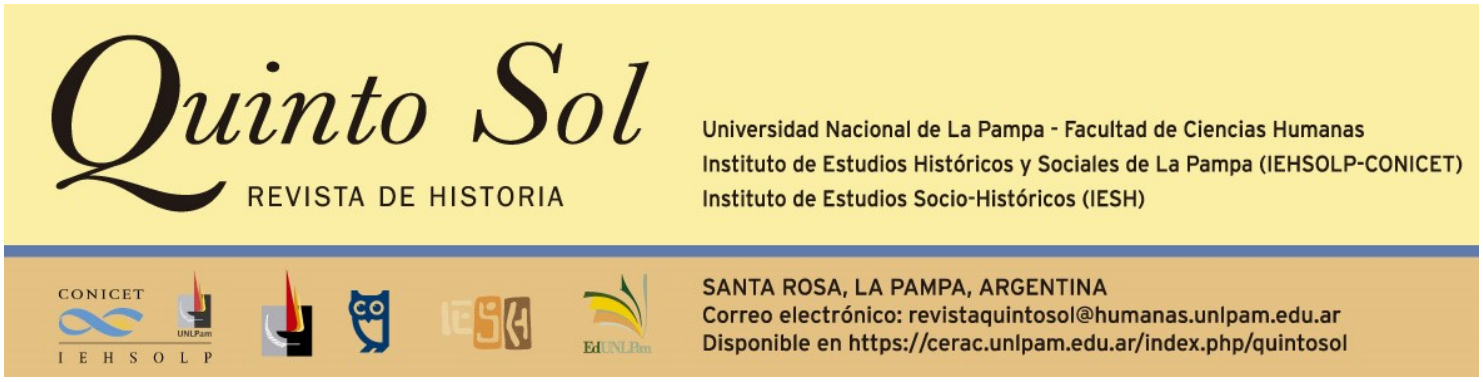

Quinto Sol, vol. 24, n 3, septiembre-diciembre 2020, ISSN 1851-2879, pp. 1-3

DOI: $\underline{\text { https://doi.org/10.19137/qs.v24i3.5270 }}$

Esta obra se publica bajo licencia Creative Commons 4.0 Internacional. (Atribución-No ComercialCompartir Igual)

\title{
Marina Franco. El final del silencio. Dictadura, sociedad y derechos humanos en la transición (Argentina, 1979- 1983). Buenos Aires: Fondo de Cultura Económica, 2018, 441 páginas.
}

\section{Ana María T. Rodríguez}

Universidad Nacional de La Pampa. Facultad de Ciencias Humanas. Facultad de Ciencias Económicas y Jurídicas Argentina

Correo electrónico: anarodriguez@humanas.unlpam.edu.ar

Acostumbrados/as a textos problematizadores, otra vez más, la historiadora Marina Franco nos acerca una nueva contribución que complejiza el conocimiento de diferentes aspectos de la sociedad argentina reciente. En esta oportunidad, con un estudio que se centra en la emergencia, configuración y visibilización del accionar de la represión y de la violación a los derechos humanos en el último tramo de la dictadura militar de 1976-1983.

La propuesta analiza un lapso que ha concitado el interés de las ciencias sociales en las últimas décadas. A decir verdad, la periodización del libro reconoce su inicio en la emergencia política del problema represivo, que toma como hito la visita de la Comisión 
Interamericana de Derechos Humanos a Argentina en 1979 y señala como corte la autoamnistía militar y las elecciones de 1983. En ese marco temporal, la investigación aborda la trayectoria de los principales actores que participaron, de algún modo visible, en la cuestión represiva. Si bien el acento principal está puesto en la Junta Militar y las Fuerzas Armadas, también la mirada se detiene en los partidos políticos, los medios de prensa, la iglesia católica, el Poder Judicial y las organizaciones de derechos humanos.

Las interpretaciones sobre "el final de la dictadura" o la "transición" a la democracia (que incluye la primera etapa del gobierno presidencial de Raúl Alfonsín) son puestas en diálogo en clave histórica. Precisamente, la autora tensiona los abordajes realizados y propone una revisión que discute las explicaciones que, por cierto, han anclado más allá del campo científico y forman parte, en gran medida, de la memoria colectiva.

El punto de partida que motivó la investigación y su desarrollo, que con posterioridad devino en esta propuesta editorial, posibilita concebir a este libro como producto de una operación historiográfica en términos de Michel de Certeau (2006) y, en ese sentido, como una combinación de un espacio social y de prácticas científicas. Confluyen en este estudio las diferentes trayectorias personales y profesionales de Marina Franco, desde el hallazgo de un nuevo material documental -el periódicoTiempo Argentino- hasta sus propias necesidades académicas de explicar cómo una sociedad experimenta, construye y procesa su relación con la violencia extrema ejercida desde el Estado.

En esta ocasión, la historiadora nos interpela y nos ofrece un bagaje empírico para pensar cómo fue posible que amplios sectores sociales pasaron de sentirse amenazados por la "subversión" y dar un fuerte consenso a la campaña represiva emprendida por la Dictadura, a condenar esa represión estatal. Asimismo, se pregunta ¿qué había pasado en el tramo final de la dictadura para llegar al "Nunca más" y a los juicio de 1985? ¿En qué momento los derechos humanos y el reclamo por los desaparecidos y la represión comenzaron a ser nodales en el discurso público dominante?

Para dar respuesta a estos interrogantes, los diferentes capítulos permiten volver a examinar aspectos vinculados a la interpretación del proceso histórico argentino que llevó a la democratización de la sociedad. En el recorrido entran en tensión explicaciones previas tales como la consideración del "caso" argentino de la "transición democrática" en el modelo de colapso, la periodización acerca del inicio y el cierre del proceso de "transición" y de "consolidación" de la democracia, la noción de crisis para dar cuenta del período y la temática de los derechos humanos analizada desde la perspectiva de los propios actores. El enfoque propuesto requiere que nos interroguemos acerca de los límites del relato construido, en tanto mirada de los sectores visibles de las clases medias profesionales y de las grandes ciudades. $\mathrm{Y}$, vinculado a esta disquisición, el texto nos invita también a cuestionarnos acerca de la sobrerrepresentación del alcance social del paradigma de los derechos humanos al final de la dictadura.

Lejos de los análisis reduccionistas y simplificados, y de los modelos que interpretan esta etapa como un camino lineal hacia la investigación y el juzgamiento de los crímenes cometidos por la dictadura, el libro nos ofrece un abordaje complejo que pone en evidencia los cambios, los reacomodamientos y los desplazamientos de la época. 
El final del silencio. Dictadura, sociedad y derechos humanos en la transición (Argentina, 1979-1983) se suma a Un enemigo para la nación. Orden interno, violencia y subversión, 1973-19761 (2012) y a la compilación de Franco y Claudia Feld titulada Democracia, hora cero. Actores, políticas y debates en los inicios de la posdictadura, para aporta al conocimiento de la emergencia de los derechos humanos y de los procesos de investigación y juzgamiento de los crímenes cometidos por las Fuerzas Armadas. Una nueva publicación que invita a ser leída para entender problemáticamente la historia reciente argentina que, en palabras de la propia autora, ayudan a repensar las "figuras cristalizadas en la memoria".

\section{Referencias bibliográficas}

1. de Certeau, M. (2006). La escritura de la historia. México DF, México: Universidad Iberoamericana.

2. Franco, M. (2012). Un enemigo para la nación. Orden interno, violencia y subversión, 1973-19761. Buenos Aires, Argentina: Fondo de Cultura Económica.

3. Franco, M. Feld, C. (Comps.) (2015). Democracia, hora cero. Actores, políticas y debates en los inicios de la posdictadura. Buenos Aires, Argentina: Fondo de Cultura Económica. 